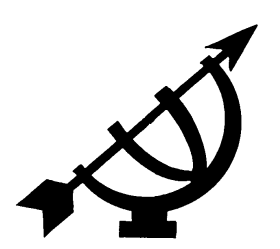

\title{
Die potensiële waarde van gesinsrituele vir betekenisgewing deur kinders
}

\author{
R. Ferreira, C.S. du Preez \& E. Archer \\ Departement Opvoedkundige Sielkunde \\ Universiteit van Pretoria \\ PRETORIA
}

E-pos: ronel.ferreira@up.ac.za

carl@ksm.co.za

emmiearcher@lantic.net

\section{Abstract \\ The potential value of family rituals in children's processes of meaning making}

This article reports on the findings of a qualitative study that explored family rituals as potential asset in children's processes of giving meaning. As such, the purpose of the study was firstly to identify the dimensions of family rituals in one family that participated; and secondly, to explore potential ways in which the participation in family rituals could influence children's processes of meaning making. The study was embedded in the interpretivist paradigm, rested on an instrumental case study design, and deployed educational psychological assessment, informal conversations, semi-structured interviews, reflective journals, visual data, observation and field notes as data collection and documentation methods. Two Afrikaans-speaking primary school children (a brother and sister) and their parents were purposefully selected as participants. During the study, the five basic dimensions of family rituals (structure, meaning, persistence and commitment, adaptability and gender relations) could be identified in the rituals practised by the participating family. In addition, six other dimensions were prominent, namely task completion, communication, roles, affective management, affective involvement and behaviour management. Based on the positive effect of family rituals on the meanings given by the participating children it is concluded that family rituals may serve as an asset within the family context and as such be employed during family intervention initiatives. 


\section{Opsomming}

\section{Die potensiële waarde van gesinsrituele vir betekenisgewing deur kinders}

Hierdie artikel doen verslag oor die bevindings van 'n kwalitatiewe studie waartydens gesinsrituele as moontlike bate tydens betekenisgewing deur kinders verken is. Die doel van die studie was eerstens om die dimensies van geselekteerde gesinsrituele te identifiseer. Tweedens is moontlike wyses ondersoek waarop die beoefening van gesinsrituele kinders se betekenisgewing kan beïnvloed asook watter bategebaseerde uitkomste die beoefening van gesinsrituele moontlik kan oplewer. Die navorsing is vanuit die interpretivistiese paradigma onderneem, het op ' $n$ instrumentele gevallestudie as navorsingsontwerp gesteun en opvoedkundig-sielkundige assesserings, informele gesprekvoering, semi-gestruktureerde onderhoude, reflektiewe joernale, visuele data, observasie en veldnotas as data-insamelings- en -vasleggingstegnieke benut. Twee Afrikaanssprekende laerskoolkinders ('n broer en suster) en hulle ouers is doelgerig as deelnemers geselekteer. Gedurende die studie kon die vyf basiese dimensies van gesinsrituele (struktuur, betekenis, volharding en toewyding, aanpasbaarheid en geslagsverhoudings) geïdentifiseer word in die rituele wat die deelnemende gesin beoefen het. Hierbenewens het ses ander dimensies prominent na vore getree, naamlik taakvoltooiing, kommunikasie, rolle, affektiewe bestuur, affektiewe betrokkenheid en gedragsbeheer. Op grond van die positiewe uitkoms van gesinsrituele op die betekenisgewing deur die deelnemende kinders aan hulself en ook die rituele waaraan hulle deelneem, word die gevolgtrekking gemaak dat gesinsrituele as moontlike bate aangewend kan word binne die konteks van die gesin. Dit volg verder dat gesinsrituele moontlik geïmplementeer kan word tydens gesinsintervensie-inisiatiewe.

\section{Inleiding en kontekstualisering}

Die gesin is een van die oudste sosiale konstrukte en 'n universele verskynsel wat wêreldwyd aangetref word. Vanuit 'n funksionalistiese perspektief het gesinne onder andere ten doel om kinders te sosialiseer en 'n bron van liefde en kameraadskap te wees. Gesinsfunksionering het egter drasties oor die afgelope 30 jaar verander. Volgens Calvert et al. (2002), asook Popenoe et al. (1998), verteenwoordig die gesin nie noodwendig meer die primêre bron van sosialisering van kinders nie, maar hierdie funksie word dikwels verskuif na die alomteenwoordige media en ander sosialiseringsagente. Indien hierdie bewerings waar is, behoort daadwerklik opgetree te word om die rolle en funksies van gesinne te herstel, ten 
einde aan kinders die geleentheid te bied om aspekte soos gesonde sosialisering, liefde en kameraadskap binne gesinsverband te kan beleef. Die vraag na hoe hierdie doelwit bereik kan word, kom uiteraard na vore.

Een moontlikheid waardeur die behoefte aan gesonde gesinsfunksionering potensieel hanteer kan word en wat as onderliggende filosofie gedien het vir die navorsing wat in hierdie artikel bespreek word, is die bategebaseerde benadering. Weens die feit dat die bategebaseerde benadering ' $n$ relatief resente benadering is, is navorsing oor die moontlike toepassingswaarde van die benadering aan die toeneem. ' $n$ Voorbeeld van 'n navorsingsgebied wat indringender ondersoek vereis, hou verband met die potensiële toepassing van die benadering binne die gesinskonteks, meer spesifiek in terme van die moontlikheid om gesinsrituele as bate aan te wend ter opheffing en voorkoming van gesinsdisfunksie. In die volgende afdeling word aandag geskenk aan die bategebaseerde benadering as onderliggende filosofiese raamwerk tot die navorsing onder bespreking, binne die konteks van gesinsfunksionering en die beoefening van gesinsrituele.

\section{Gesinsrituele as moontlike bate binne die raamwerk van die bategebaseerde benadering}

Gesinsrituele verwys na interaksie tussen gesinslede wat ' $n$ simboliese vorm van kommunikasie insluit en gesinslede van 'n niebedreigende manier voorsien om uitdagings binne gesinsverband te hanteer (Mackey \& Greif, 1994). Dit is herhalend van aard, versterk gewoonlik die gesin se identiteit en sluit dikwels die beoefening van roetine in (Fiese \& Marjinsky, 1999; Schuck \& Bucy, 1997; Baxter \& Clark, 1996; Mackey \& Greif, 1994). Gesinsrituele verskil van gesinsroetines. Gesinsroetines verwys na waarneembare en herhalende gesinsgedrag, sonder die noodwendige teenwoordigheid van die simboliese en antisiperende aard wat kenmerkend is van gesinsrituele. Vanweë die aard van gesinsrituele word die beoefening van rituele dikwels verbind met gesinne wat emosioneel gesond is (Howe, 2002; Mackey \& Greif, 1994).

Hierdie verband bevestig die moontlike waarde van gesinsrituele as hulpmiddel of bate. Dit impliseer uiteraard 'n moontlike verband met die bategebaseerde benadering. Die bategebaseerde benadering fokus daarop om die beste in gesinne (individue) na vore te bring ten einde effektiewe funksionering en welstand te bevorder (Nichols \& Schwartz, 2000). Die benadering spruit uit die veld van die 
Positiewe Sielkunde, wat sterk punte, talente en ander aspekte van gesondheid en welstand bestudeer, sonder om probleme en uitdagings te ontken. Hierdie perspektief herbalanseer die oorbeklemtoning van patologie in die Sielkunde wat vir jare tot ' $n$ groot mate deur die mediese model en psigoanalitiese benaderings beïnvloed is (Wenar \& Kerig, 2005; St. Clair, 2004; Seligman, 2002; Miller \& Crabtree, 2000).

Die bategebaseerde benadering begin by dit wat reeds teenwoordig is, met ander woorde die bates en kapasiteite van individue en sisteme. Binne die raamwerk van die bategebaseerde benadering kan die konsep bate verder verfyn word in terme van bestaande vaardighede, talente, gawes, hulpbronne en sterkpunte wat gedeel word deur individue, instansies, verenigings, die gemeenskap en organisasies (Ebersöhn \& Eloff, 2006; Kretzmann \& McKnight, 1993). Bates sluit derhalwe enige bestaande en potensiële hulpbronne in waarop gesteun kan word wanneer uitdagings hanteer of welstand bevorder wil word, binne individue of sisteme soos gesinne. In hierdie konteks kan die beoefening van gesinsrituele uiteraard as voorbeeld dien.

In teenstelling met 'n probleemgesentreerde perspektief word die terapeutiese verhouding binne die bategebaseerde benadering gekenmerk deur samewerking, bemagtiging van kliënte in terme van potensiaal en 'n ontginning van hulpbronne. Die fokus op oorsake van probleme is minder prominent, en word vervang deur 'n klem op oplossings wat gegenereer kan word deur die bestaande en potensiële vaardighede van kliënte, hulle gesinne en ander onmiddellike sisteme te identifiseer en te mobiliseer (Ebersöhn \& Eloff, 2006; Nichols \& Schwartz, 2000). Dit volg dat gesinsrituele moontlik aangewend kan word as hulpbron binne gesinsverband om optimale gesinsfunksionering te bevorder.

\section{Die navorsing}

In die lig van die voorafgaande bespreking, die toenemende noodsaaklikheid om die welstand van hedendaagse gesinne (meer spesifiek kinders) te bevorder asook die behoefte aan navorsing wat verband hou met die bategebaseerde benadering binne die gesinskonteks, is 'n kwalitatiewe studie onderneem. Hierdie studie moes die moontlike invloed van gesinsrituele (as bate) tydens betekenisgewing deur kinders binne gesinsverband ondersoek. Die doel van die navorsing was eerstens om die dimensies van die gesinsrituele van die kerngesin wat aan die studie deelgeneem het, te identifiseer. Tweedens is dit ten doel gestel om moontlike wyses te 
identifiseer waarop die beoefening van gesinsrituele betekenisgewing deur kinders kan beïnvloed, asook watter bategebaseerde uitkomste potensieel daarmee verband kan hou. Die navorsingsfokus en bevindings impliseer moontlike toepassingswaarde van gesinsrituele as terapeutiese middel in opvoedkundig-sielkundige praktyk, asook ander steungewende professies, waar die einddoel verband hou met die emosionele welstand en gesonde funksionering van kinders binne hulle gesinne.

\subsection{Onderliggende navorsingsparadigma en navorsings- ontwerp}

Weens die spesifieke aard en omvang van die navorsing is op die interpretivistiese paradigma as onderliggende beskouing van die realiteit gesteun. Die kwalitatiewe, interpretivistiese benadering het die navorsers in staat gestel om die persepsies en belewings van die deelnemers aangaande die beoefening van gesinsrituele binne hulle unieke natuurlike omgewing (die huisgesin) te verken op 'n wyse wat vir hulle betekenisvol was. As kwalitatief-interpretivistiese navorsers is die feit dat deelnemers self hulle eie betekenisse en sosiale realiteite skep, deurgaans gerespekteer (Denzin \& Lincoln, 2003; Terre Blanche \& Durrheim, 2002; Schwandt, 2000). Verder is ook in gedagte gehou dat sosiale realiteite beïnvloed word deur sosiale situasies, kontekste waarbinne funksionering plaasvind (soos die gesinskonteks) en die spesifieke tyd waartydens betekenisgewing geskied (Cohen et al., 2000).

Die gekose navorsingsbenadering en onderliggende filosofie het die navorsers in staat gestel om insig te verkry in die subjektiewe ervarings en sienings van die deelnemers. In ooreenstemming met die navorsingsbenadering en doel van die studie, is van 'n instrumentele gevallestudie as navorsingsontwerp gebruik gemaak (McMillan \& Schumacher, 2001; Stake, 2000).

\subsection{Deelnemers aan die studie}

Twee Afrikaanssprekende laerskoolkinders (en hulle ouers) is doelgerig vir die navorsing geselekteer. Die kinders, 'n broer en suster, was ten tye van die studie onderskeidelik 9 en 11 jaar oud. Die navorsers het die veldwerk by die deelnemers se woning gedoen, in die natuurlike omgewing waarbinne die gesinsrituele beoefen word en vanweë die verwagting dat die data wat daar ingesamel is, weerspieëlings van die werklike gesinsgebeure sou wees. 


\subsection{Data-insameling, -vaslegging en -analise}

Veelvuldige data-insamelings- en -dokumenteringsmetodes is gebruik om data direk van die deelnemers te bekom. Eerstens is opvoedkundig-sielkundige assesserings gebruik om die kinders se betekenisgewing te bepaal. Postmodernistiese tegnieke wat tradisioneel vir intervensie gebruik word (collages, asook tekeninge van die gesin en die onderskeie gesinsrituele) is vir navorsingsdoeleindes aangewend. Hierbenewens en gelyklopend met die assesserings is op semi-gestruktureerde onderhoude met die kinders en hulle ouers gesteun om data te bekom. Hierdie data sou verband hou met die gesinsrituele wat binne die geselekteerde gesin beoefen is ten tye van die veldwerk, die aard en onderliggende prosesse daarvan, asook die onderskeie deelnemers se belewings en persepsies daaromtrent (Patton, 2002; Cohen et al., 2000).

Deelnemers is versoek om gereeld skriftelik te reflekteer oor die gesinsrituele wat die gesin implementeer, asook oor hulle belewings daarvan. Ter inleiding van hierdie aktiwiteit is aan die kinders verduidelik dat refleksies hulle beskrywings, gedagtes, gevoelens en belewings van die rituele sou behels. Op hierdie wyse is inligting versamel in die vorm van protokolle. Daar is op oop vrae gesteun ten einde die deelnemers te bemagtig om hulle eie response te formuleer (Creswell, 2005). Verder is ook van observasie, visuele data (in die vorm van foto's en die produkte van die opvoedkundigsielkundige assesserings van die kinders), reflektiewe joernale en veldnotas gebruik gemaak.

Tydens data-analise is die proses en riglyne vir tematiese analise (soos voorgestel deur Creswell, 2005) gevolg. Nadat die rou data ingesamel en vir ontleding voorberei is, is deur die data gelees ten einde ' $n$ algemene indruk oor die inhoude te ontwikkel. Daarna is die rou data gekodeer en is temas geïdentifiseer wat in kategorieë gesorteer is. Laastens is die geïdentifiseerde temas en subtemas in verband gebring met bestaande literatuur ten einde tot finale bevindings te kon kom.

Gedurende die onderskeie data-insamelings, -vasleggings- en analisehandelinge is etiese navorsingsbeginsels gehoorsaam, naamlik dié van outonomie, die beskerming van deelnemers en die aanwending van navorsing tot voordeel van die gemeenskap (Terre Blanche \& Durrheim, 2002). As sodanig is die beginsels van vrywillige deelname, ingeligte toestemming en konfidensialiteit gerespekteer. Hierbenewens is die etiese kode van die Raad vir Gesondheidsberoepe 
in Suid-Afrika (HPCSA) tydens alle kontak met die deelnemers gehoorsaam.

\section{Resultate en bevindings van die ondersoek}

Veldwerk het oor nege weke gestrek en vier kontakgeleenthede met die gesin behels, waartydens vier rituele geïdentifiseer is wat die gesin gereeld beoefen. Die rituele was naamlik dat die gesin saans saam stories lees, gereeld saam fietsry, swem of stap, saam vuurmaak in die winter terwyl hulle Sewende laan kyk, en sekere rituele beoefen tydens bad- en slaaptyd. Voorbeelde hiervan is dat die kinders saam met die moeder by kerslig bad en 'n rukkie saam met een van hulle ouers gaan lê wanneer hulle wil gaan slaap. Vervolgens word die temas wat tydens data-analise verkry is, wat verband hou met die genoemde gesinsrituele, bespreek.

\subsection{Dimensies van die gesinsrituele wat deur die deel- nemende gesin beoefen is}

Bestaande literatuur identifiseer vyf breë dimensies wat tipies by gesinsrituele aanwesig is, naamlik struktuur, betekenis, volharding en toewyding, aanpasbaarheid en geslagsverhoudings (Dubas \& Gerris, 2002; Schuck \& Bucy, 1997; Roberts, 1988). Uit die data-analise het dit geblyk dat al hierdie dimensies teenwoordig was binne die konteks van die wyse waarop die deelnemende gesin hulle gesinsrituele beoefen het ten tye van die studie. Die moeder verwys byvoorbeeld in 'n onderhoud na die struktuur wat gevolg word tydens die gesin se gesamentlike fietsryritueel: "Dan ry ons almal op en gaan eet roomys en dan ry ons met die paadjie terug."

Wat betref volharding en toewyding (Schuck \& Bucy, 1997), is bevind dat die kinders waarskynlik meer volhardend en toegewyd aan die rituele was as hulle ouers. In hierdie verband meld die vader tydens 'n onderhoud dat "die grootmense het nie altyd die energie nie", maar teken in sy refleksiejoernaal aan dat "Die kinders is altyd gretig ...". Tog het die resultate verskeie faktore uitgelig wat moontlik ook die kinders se volharding en toewyding negatief kon beïnvloed, onder andere skoolverwante druk wat moegheid veroorsaak, persoonlike voorkeure en daaglikse roetine-aktiwiteite. Die moontlikheid is egter geïdentifiseer dat sodanige roetine-aktiwiteite ook in gesinsrituele omskep kan word wat dan simboliese betekenis vir gesinslede inhou sodra dit beweeg vanaf 'n instrumentele na 'n simboliese vlak (Fiese et al., 2002). Hierdie moontlikheid, asook die feit dat die gesin wel gesinsrituele beoefen het ten spyte van druk programme, lei tot die gevolgtrekking dat die deelnemende gesin daaglikse 
roetine-aktiwiteite op sodanige wyse bestuur dat die beoefening van gesinsrituele moontlik kan optimaliseer.

Die bevinding dat werksverpligtings en kompeterende belange soos skoolverwante druk die beoefening van gesinsrituele vir die deelnemende gesinslede bemoeilik het, word bevestig deur bestaande navorsing soos dié van Dubas en Gerris (2002). Benewens hierdie faktore is ook verdere aspekte geïdentifiseer wat die beoefening van gesinsrituele kan bemoeilik, soos die seisoen van die jaar en die tyd van die dag waarop die gesinsritueel plaasvind. Die oënskynlike variasie tussen hierdie navorsingsresultate en bevindings wat in bestaande literatuur gereflekteer word, kan moontlik toegeskryf word aan die feit dat die gesin wat aan die huidige studie deelgeneem het, in unieke omstandighede oor unieke lewensuitkyke en waardestelsels beskik wat waarskynlik verskil van dié van die deelnemers aan ander studies wat dikwels in die buiteland onderneem word. Verder het hierdie studie 'n enkele gesin gebruik, terwyl ander studies dikwels veelvuldige deelnemers insluit.

In terme van die algemene uitspraak dat televisie dikwels die rol van gesinstyd oorneem (vgl. Dubas \& Gerris, 2002; Larson et al., 2001), dui die huidige resultate die teendeel aan. Die deelnemende gesin het 'n gesinsritueel gevorm wat verband hou met die kyk van 'n televisieprogram (Sewende laan) wat gesprekvoering en gevolglik ook moontlik gesinsverhoudings kan bevorder. Hoewel hierdie roetine by dié spesifieke gesin moontlik daaraan toegeskryf kan word dat die gesin voorheen in die buiteland gewoon het waartydens hulle geen Afrikaanse televisieprogramme kon kyk nie, dui die bevinding daarop dat die invloed van televisie binne gesinsverband nie noodwendig altyd negatief is nie. Hierdie uitspraak is egter 'n hipotese, wat verder nagevors moet word ten einde tot 'n wetenskaplike uitspraak te kan kom.

In aansluiting by, maar ook ter uitbreiding van die vyf basisdimensies wat gewoonlik by gesinsrituele ingesluit word, fokus Dickstein (2002) op ses dimensies van gesinsfunksionering, naamlik probleemoplossing en taakvoltooiing, kommunikasie, rolle, affektiewe bestuur, affektiewe betrokkenheid en gedragsbeheer. Al ses hierdie dimensies kon by die deelnemende gesin, tydens die beoefening van die gesinsrituele wat bestudeer is, geïdentifiseer word. Op grond van hierdie resultaat en die uitgangspunt dat gesinsrituele 'n vorm van gesinsfunksionering is, kan die voorstel gemaak word dat rituele slegs as gesinsrituele geklassifiseer kan word indien dit die ses dimensies van Dickstein (2002) insluit. 


\subsection{Moontlike invloed van die beoefening van gesinsrituele op die betekenisgewing deur kinders}

Die betekenisgewing van die kinders wat aan die navorsing deelgeneem het, is op drie vlakke deur die beoefening van gesinsrituele beïnvloed. Die invloed was in terme van die betekenisse wat hulle aan hulle primêre opvoedingsgesitueerdheid gee, die betekenisse wat hulle aan gesinsrituele as sodanig gee, en die betekenisse wat hulle aan hulself gee. Hierbenewens is enkele negatiewe betekenisgewings tydens data-analise geïdentifiseer.

\subsubsection{Betekenisse van die deelnemende kinders aan hulle primêre opvoedingsgesitueerdheid}

Die kinders het hulle primêre opvoedingsgesitueerdheid beteken as 'n konteks wat sekuriteit verleen, 'n gevoel van vrede skep en waarbinne hulle die ouers kan nader vir hulp en raad. Hierdie resultaat word soos volg saamgevat in veldnotas wat tydens die derde kontaksessie met die kinders gemaak is, kort nadat die gesin 'n huisinbraak beleef het: "Al twee kinders toon, alhoewel bietjie ontstel deur die gebeure, steeds ' $n$ sin vir sekuriteit en veiligheid in die tuisomgewing, ten spyte van die inbraak." Binne die omvang van die studie, kon 'n moontlike verband tussen sodanige betekenisgewings en die oënskynlike demokratiese opvoedingstyl van die deelnemende ouers egter geïdentifiseer word.

Hierdie moontlike verband is gebaseer op die bevinding dat die ouers se sensitiwiteit vir die behoeftes van hulle kinders waarskynlik aan hulle 'n sin van sekuriteit kon verleen, asook die wete dat hulle ander mense kan vertrou (Wenar \& Kerig, 2005; Louw et al., 1998; Ainsworth et al., 1978). Indien ouers demokraties optree tydens interaksie met hulle kinders wanneer gesinsrituele beoefen word, kan die hipotese geformuleer word dat kinders as gevolg hiervan moontlik hulle opvoedingsgesitueerdheid as veilig en beskermend sal beleef en beteken. Voorts kan die afleiding gemaak word dat sodanige kinders, weens 'n sin van sekuriteit, ook moontlik vrede sal ervaar en hulle ouers met vrymoedigheid sal nader vir hulp en raad. Hierdie redenasie is egter ' $n$ hipotese wat verdere ondersoek noodsaak.

\subsubsection{Betekenisse van die deelnemende kinders aan gesins- rituele}

Uit die resultate wat verkry is, het dit geblyk dat die kinders gesinsrituele in 'n positiewe lig beteken. Hulle het aangedui dat hulle graag 
deelneem aan die geïdentifiseerde rituele en daarna verlang in tye wanneer dit nie beoefen word nie. Hierdie resultate kan in verband gebring word met literatuur uit die Positiewe Sielkunde, wat betrekking het op die mens se emosionele welstand en geluk. Volgens Compton (2005) bestaan 'n betekenisvolle korrelasie tussen geluk en die vlakke van tevredenheid met aktiwiteite wat mense in hulle vrye tyd beoefen. Indien aangeneem word dat die deelnemende gesin se gesinsrituele as sodanige (positiewe) aktiwiteite beleef is, kan die afleiding gemaak word dat die kinders 'n hoë mate van tevredenheid met die gesinsrituele ondervind het weens die feit dat dit hulle gelukkig maak. Hierdie hipotese verlang verdere ondersoek.

Die resultate van die navorsing dui verder daarop dat die beoefening van gesinsrituele bepaalde voordele vir kinders kan inhou. Volgens die kinders het die beoefening van gesinsrituele vir hulle byvoorbeeld die voordeel ingehou dat hulle op grond van hulle deelname bepaalde ander aktiwiteite kon vermy. Indien die deelnemende kinders se stadium van kognitiewe ontwikkeling - aldus Piaget se teorie van kognitiewe ontwikkeling - egter in ag geneem word (Louw et al., 1998), kan die afleiding gemaak word dat hulle (eie aan die konkreet-operasionele fase) na afloop van die beoefening van gesinsrituele, moontlik sekere konkrete voordele kon beleef wat daardeur teweeg gebring is. Op hierdie wyse sou hulle betekenisgewing aan gesinsrituele dienooreenkomstig positief beïnvloed word. Hierdie hipotese kan eweneens verder nagevors word ten einde 'n wetenskaplik gefundeerde uitspraak te kan lewer.

\subsubsection{Betekenisse van die deelnemende kinders aan hulself}

Die resultate dui aan dat die beoefening van gesinsrituele (met bepaalde uitsonderings) die kinders se betekenisgewing aan hulself positief beïnvloed het. Die opvoedkundig-sielkundige assesserings dui byvoorbeeld daarop dat die kinders se betekenisgewing verband hou met 'n positiewe selfkonsep, selfvertroue en 'n goeie waaghouding. Oswald (2002) verskaf 'n moontlike verklaring vir sodanige positiewe betekenisgewing: die blote feit dat 'n persoon (kind) aan 'n gesin behoort en deur 'n gesin ingesluit word, is 'n belangrike faktor wat geassosieer kan word met 'n positiewe impak van gesinsrituele op die individuele ontwikkeling en welstand. Die moontlikheid bestaan dat individue (kinders) makliker by nuwe omstandighede sal aanpas indien hulle voel dat hulle aan 'n groep (gesin) behoort (Bennett et al., 1988). Daar kan dus afgelei word dat kinders se positiewe betekenisgewing aan hulself op grond van die beoefening van gesinsrituele suksesvolle aanpassing in nuwe omstandighede as bategebaseerde uitkoms tot gevolg mag hê. 
Die opvoedkundig-sielkundige assesserings, onderhoude en refleksies dui verder daarop dat die kinders hulself beleef het as waardig vir hulle ouers se aandag en liefde, as spesiaal en geliefd, en as rolspelers in die ander gesinslede se lewensverryking en groei. Sodanige belewing van sosiale bevoegdheid (vgl. Wenar \& Kerig, 2005) kan uiteraard bydra tot die ontwikkeling van 'n positiewe selfkonsep. Dit blyk uit die resultate en data soos die volgende: "Ek voel confident as ons saam lees." (Geneem uit die dogter se refleksiejoernaal.) Hierbenewens kon die blote deelname aan rituele binne gesinsverband dalk ook tot die verbetering van die kinders se selfkonsep aanleiding gegee het, soos bevind is in 'n studie deur Dengel (2000). In aansluiting by Dengel (2000) kan die toename in selfvertroue, waaghouding en 'n positiewe selfkonsep as bategebaseerde uitkomste van betekenisgewing deur kinders beskou word, wat verband hou met deelname aan gesinsrituele. Hierdie beskouing word deur Fiese en Kline (1993) bevestig wat in 'n studie bevind het dat gesinsrituele inderdaad adolessente en kinders se selfbeeld positief kan beïnvloed.

\subsubsection{Negatiewe betekenisgewing deur die deelnemende kinders}

Benewens die moontlike positiewe uitkomste van gesinsrituele op die betekenisgewing deur kinders, is bevind dat die beoefening van gesinsrituele soms ook tot negatiewe betekenisgewing deur die deelnemende kinders gelei het. Imber-Black (2002) beskou gesinsrituele as 'n kragtige lens wat 'n mens kan bemagtig om emosionele bande en verhoudings duidelik te sien. Teen hierdie agtergrond dui die resultate daarop dat sporadiese problematiese interaksie tussen die deelnemende gesinslede waarskynlik deur die beoefening van gesinsrituele onder die vergrootglas geplaas is.

'n Voorbeeld van negatiewe betekenisgewing hou verband met die betekenisse wat die seun aan gesinsrituele en aan homself toegeken het en wat in bepaalde negatiewe uitkomste geresulteer het. Die seun het bepaalde gesinsrituele beteken as geleenthede waartydens hy deur ander gesinslede aangeval word (onder andere wanneer hy uit die Bybel moes voorlees). Hy het homself per geleentheid selfs as stout beteken op grond van negatiewe terugvoer deur ander gesinslede, toe hy self 'n Bybelgedeelte gekies het en nie aan die ouers se voorstel gehoor gegee het nie. Die positiewe betekenisse wat deur die kinders aan die beoefening van gesinsrituele beteken is, het egter deurgaans die enkele voorbeelde van negatiewe betekenisgewing oorskadu. 


\subsection{Bategebaseerde uitkomste van die beoefening van gesinsrituele}

Uit die data wat bekom is, het dit geblyk dat die beoefening van gesinsrituele bategebaseerde uitkomste opgelewer het op drie verskillende vlakke van gesinsfunksionering. Hierdie vlakke behels die interaksie tussen gesinslede, die algemene welstand van gesinslede, en die opvoedkundige vlak van funksionering. Nieteenstaande die gemelde resultaat wat verband hou met die seun se enkele negatiewe belewings, is bevind dat die gesinsrituele wat beoefen is die verhoudings tussen gesinslede oor die algemeen versterk het. Die gesinslede het naamlik deur gereelde interaksie die geleentheid gekry om mekaar beter te leer ken en mekaar wedersyds te ondersteun. Dit blyk uit 'n inskrywing in die dogter se refleksiejoernaal: "My gesin is die beste. Ons doen lekker goed saam."

'n Studie deur Fiese et al. (2002) bevestig hierdie resultaat dat rituele gesinsverhoudings moontlik kan versterk. Die bevinding kan waarskynlik selfs verder uitgebrei word na die moontlikheid van verbeterde verhoudings op 'n wyer vlak, indien dit teen die agtergrond van 'n studie deur Dubas en Gerris (2002) beskou word. Daarvolgens kan die hoeveelheid tyd wat ouers en kinders tydens vroeë adolessensie saam spandeer die kwaliteit van verhoudings met mekaar in die latere adolessente jare bepaal.

Die resultate wat verkry is, het verder aangedui dat die beoefening van gesinsrituele geleenthede geskep het vir die gesin om tyd saam te spandeer, ten spyte van 'n besige skedule. Op grond van die verkreë resultate kan afgelei word dat hierdie bevinding oor die tyd wat die gesin saam spandeer, moontlik verband hou met sekere van die ander bategebaseerde uitkomste. Sodanige bategebaseerde uitkomste is naamlik dat gesinsrituele herinneringe kan skep wat die gesinslede kan saambind, dat gesinsrituele tot minder aandagsoekerige gedrag by kinders kan lei, dat dit toekomstige probleme kan voorkom en dat dit die geleentheid aan kinders kan bied om hulle behoeftes aan hulle ouers bekend te maak.

Bogenoemde verbande tussen die bevindings kan ten beste geillustreer word in die hipotetiese afwesigheid van gesinsrituele. Indien die gesin wat aan hierdie studie deelgeneem het geen gesinsrituele beoefen het nie, sou hulle geen herinneringe daarvan kon deel nie. Hierdie aanname sluit aan by die navorsing van Pasupathi (2001) wat aandui dat gesinsrituele dikwels geleenthede voorsien vir die groepsvorming van outobiografiese geheue wanneer gesinslede saam oor herinnerings gesels. Verder sou die kinders wat aan die 
studie deelgeneem het in die afwesigheid van gesinsrituele waarskynlik meer aandagsoekerige gedrag geopenbaar het, aangesien hulle die tyd ontneem sou wees waarin die ouers aan hulle aandag skenk. Aangesien die kinders in die afwesigheid van gesinsrituele dalk ook nie die geleentheid sou hê om hulle behoeftes bekend te maak nie, sou die ouers waarskynlik nie die nodige leiding aan die kinders kon gee om toekomstige probleme te voorkom nie.

Op 'n opvoedkundige vlak hou die bategebaseerde uitkomste wat opgelewer is eerstens verband met die moontlikheid om gesinsrituele as onderrigmedium te implementeer, waardeur kennis van geslag tot geslag oorgedra kan word. Tweedens kan kinders se sosiale vaardighede moontlik deur die beoefening van gesinsrituele bevorder word. Gesinsrituele kan op dié wyse as sosialiseringsmiddel ingeskakel word wanneer gesinswaardes en -oortuigings daardeur oorgedra word (vgl. Schuck \& Bucy, 1997). Derdens het dit geblyk dat godsdienstige waardes moontlik deur die beoefening van gesinsrituele oorgedra kan word; en vierdens het gesinsrituele binne die konteks van die navorsing aan die deelnemende ouers die geleentheid gebied om gewenste gedrag vir hulle kinders te modelleer.

Verdere bategebaseerde uitkomste wat die beoefening van gesinsrituele op 'n opvoedkundige vlak kan oplewer, sluit in dat, afhangende van die aard van die gesinsritueel, dit oor die potensiaal beskik om gesinslede se algemene kennis te verbreed en skolastiese vaardighede te bevorder. Tydens die navorsing is byvoorbeeld bevind dat die beoefening van gesinsrituele 'n positiewe uitwerking gehad het op die deelnemende kinders se akademiese prestasies. Hierbenewens wou dit voorkom asof die gesinsrituele wat beoefen is die potensiaal ingehou het om die deelnemende kinders bloot te stel aan ander aktiwiteite as wat tradisioneel in skole gefasiliteer word. Die volgende opmerking deur die moeder tydens 'n onderhoud demonstreer hierdie gedagte: "Ek sou sê dit is om hulle bloot te stel aan iets wat hulle vir die res van hulle lewe kan doen."

In terme van die algemene welstand van die gesinslede wat aan hierdie studie deelgeneem het, strook die bevindings wat verband hou met moontlike bategebaseerde uitkomste met die inhoude vervat in bestaande literatuur (Oswald, 2002; Brock, 2000; Schuck \& Bucy, 1997). Benewens die positiewe uitwerking wat die beoefening van gesinsrituele op die deelnemende gesinslede se fisieke gesondheid gehad het, het die deelnemers aangedui dat die beoefening van gesinsrituele hulle gehelp het om spanning te verlig en stres makliker te hanteer. 'n Inskrywing in die vader se refleksiejoernaal 
vat hierdie uitkoms op gepaste wyse saam: "Die vasvra verlig sommer die gemoedere, want dit is pret!"

\section{Bespreking}

Vanuit die bevindings van hierdie studie kan die gevolgtrekking gemaak word dat gesinsrituele wel as 'n bate gedien het tydens betekenisgewing deur die kinders wat aan die studie deelgeneem het. Benewens die bevinding dat die beoefening van gesinsrituele daartoe gelei het dat die deelnemende kinders gesinsrituele en hulself as positief beteken het, het die beoefening van gesinsrituele in bepaalde bategebaseerde uitkomste geresulteer, wat verband hou met die kinders se betekenisgewing. Weens die potensiële waarde wat deur gesinsrituele geïmpliseer word, kon die navorsers die moontlike terapeutiese waarde van gesinsrituele besef, wat aangewend kan word om bategebaseerde uitkomste te fasiliteer tydens intervensie met individue en/of hulle gesinne. Hierdie navorsing het nie ten doel gehad om die terapeutiese waarde van gesinsrituele te ondersoek nie. Die gevolgtrekkings wat verband hou met die identifikasie van terapeuties waardevolle elemente, wat dikwels gepaard gaan met die beoefening van gesinsrituele, kan egter prakties aangewend word tydens gesinsintervensie deur persone in steungewende professies.

In terme van die dimensies waarvanuit gesinsrituele bestudeer kan word, kan die gevolgtrekking gemaak word dat die geïdentifiseerde dimensies soos vervat in bestaande literatuur, beperk in omvang is en uitgebrei behoort te word. Toevoegings tot die bestaande vyf dimensies van gesinsrituele kan byvoorbeeld in terme van die ses dimensies van die McMaster-model van gesinsfunksionering gemaak word. Op hierdie wyse kan problematiese gesinsfunksionering wat verband hou met aspekte soos probleemoplossing en taakvoltooiing, kommunikasie, rolle, affektiewe bestuur, affektiewe betrokkenheid en gedragsbeheer, moontlik meer effektief deur middel van gesinsrituele behandel word.

Alhoewel die beoefening van gesinsrituele as 'n natuurlike verskynsel verwerklik is by die gesin wat aan die studie deelgeneem het, is bevind dat sekere faktore die gesinslede se volharding en toegewydheid aan die beoefening van gesinsrituele negatief beïnvloed het. Hieruit kan die afleiding gemaak word dat, indien gesinsrituele op 'n terapeutiese wyse gebruik sou word, intervensie waarskynlik noodsaaklik sal wees om sodanige faktore te bestuur en gesinne te begelei om te volhard. 'n Belangrike aspek wat hiermee verband hou en wat in die resultate van die studie na vore gekom 
het, hou verband met die feit dat die deelnemende kinders die gesinsrituele geniet het en hulle genot geverbaliseer het (vandaar hulle hoër vlak van toegewydheid as dié van hulle ouers).

Die navorsers is van mening dat hedendaagse gesinne dit dikwels uitdagend vind om gesinsverhoudings in stand te hou, in die lig van die realiteit van besige skedules en die eise van daaglikse roetineaktiwiteite. Ten spyte hiervan dui die resultate van die studie daarop dat versterking van gesinsverhoudings wel kan geskied deur die beoefening van gesinsrituele. Indien versterkte gesinsverhoudings nagestreef word, kan gesinsrituele dus moontlik as middel aangewend word om positiewe uitkomste te bereik. Verder skep die beoefening van gesinsrituele gedeelde herinneringe wat toekomstige interaksies tussen gesinslede positief kan beïnvloed. Die gevolgtrekking kan dus gemaak word dat interaksies tussen gesinslede moontlik beïnvloed kan word deur die manipulering van gesinsrituele wat herinnerings bou.

Wat betref die moontlike negatiewe uitkomste wat met die beoefening van gesinsrituele geassosieer kan word, meen die navorsers dat die beoefening van gesinsrituele moontlik reeds bestaande problematiese dinamiek tussen gesinslede onder die vergrootglas kan plaas en dus tot negatiewe betekenisgewing aanleiding kan gee. Die problematiese dinamiek waarna verwys word, word egter nie noodwendig deur die beoefening van gesinsrituele geskep nie. Gesinsrituele belig slegs problematiese dinamiek in gesinne en kan moontlik as instrument aangewend word tydens diagnostiese assessering asook tydens intervensie om sodanige dinamiek te behandel.

\section{Slotopmerking}

Alhoewel die aard en beperkte omvang van die studie onder bespreking die moontlikheid van volledigheid uitskakel, dui die bevindings wat verkry is daarop dat die kinders wat deelgeneem het, wel positiewe betekenisse aan gesinsrituele geheg het as gevolg van die positiewe gevoelens wat hulle daarmee assosieer. Dit volg dat die beoefening van gesinsrituele geassosieer kan word met positiewe betekenisgewing deur kinders - aan die rituele, hulself en die gesinskonteks in die breë.

Uitsonderings kom egter soms voor, wat die moontlikheid impliseer dat die beoefening van gesinsrituele by kinders soms tot negatiewe betekenisgewing kan lei, veral wanneer hulle die ritueel of hulself in 'n negatiewe lig beleef. Desnieteenstaande hou die beoefening van 
gesinsrituele verskeie bategebaseerde uitkomste in. Vanuit die Positiewe Sielkunde (Seligman, 2002) impliseer die beoefening van gesinsrituele die moontlikheid dat bates soos gesondheid, tevredenheid, geluk, blydskap, optimisme, hoop, geloof, kapasiteit vir liefde, moed, deursettingsvermoë, vergifnis, oorspronklikheid, wysheid, verantwoordelikheid, vertroeteling en altruïsme deel kan uitmaak van die lewens van hedendaagse kinders, gesinne en gemeenskappe.

\section{Geraadpleegde bronne}

AINSWORTH, M.D.S., BLEHAR, M.C., WALTER, E. \& WALL, S. 1978. Patterns of attachment. Hillside: Erlbaum.

BAXTER, L.A. \& CLARK, C.L. 1996. Perceptions of family communication patterns and the enactment of family rituals. Western journal of communication, 60(3):254-269.

BENNETT, L.A., WOLIN, S.J. \& McAVITY, K.J. 1988. Family identity, ritual and myth: a cultural perspective on life cycle transition. (In Falicov, C.J., ed. Family transitions. New York: Guilford. p. 178-189.)

BROCK, B.J. 2000. TV free families: are they Lola Granolas, normal Joes or high and holy snots? http://www.tvturnoff.org/brocksumm.htm Date of access: 13 Sept. 2005.

CALVERT, S.L., JORDAN, A.B. \& COCKING, R.R. 2002. Children in the digital age: influences of electronic media on development. Westport: Praeger.

COHEN, L., MANION, L. \& MORRISON, K. 2000. Research methods in education. London: Routledge.

COMPTON, W.C. 2005. An introduction to positive psychology. Belmont: Wadsworth.

CRESWELL, J.W. 2005. Educational research: planning, conducting, and evaluating quantitative and qualitative research. California: Sage.

DENGEL, J. 2000. Family rituals and traditions - now more important than ever. http://preschoolerstoday.com/resources/articles/traditions.htm Date of access: 13 Sept. 2005.

DENZIN, N.K. \& LINCOLN, Y.S. 2003. The landscape of qualitative research: theories and issues. California: Sage.

DICKSTEIN, S. 2002. Family routines and rituals - the importance of family functioning: comment on the special section. Journal of family psychology, 16(4):441-444.

DUBAS, J.S. \& GERRIS, J.R.M. 2002. Longitudinal changes in the time parents spend in activities with their adolescent children as a function of child age, pubertal status, and gender. Journal of family psychology, 16:415-427.

EBERSÖHN, L. \& ELOFF, I. 2006. Linking life skills and the asset-based approach conceptually and contextually. (In Ebersöhn, L. \& Eloff, I., ed. Life skills and assets. Pretoria: Van Schaik. p. 3-10.)

FIESE, B.H. \& KLINE, C.A. 1993. Development of the family ritual questionnaire: initial reliability and validation studies. Journal of family psychology, 6:290-299. 
FIESE, B.H. \& MARJINSKY, K.A.T. 1999. Dinnertime stories: connecting family practice with relationship beliefs and child adjustment. Monographs of the Society for Research in Child Development, 64(2):52-69.

FIESE, B.H., TOMCHO, T.J., DOUGLAS, M., JOSEPHS, K., POLTROCK, S. \& BAKER, T. 2002. A review of 50 years of research on naturally occurring family routines and rituals: cause for celebration. Journal of family psychology, 16(4):381-390.

HOWE, G.W. 2002. Integrating family routines and rituals with other family research paradigms: comment on the special section. Journal of family psychology, 16(4):437-440.

IMBER-BLACK, E. 2002. Family rituals - from research to the consulting room and back again: comment on the special section. Journal of family psychology, 16(4):445-446.

KRETZMANN, J.P. \& McKNIGHT, J.L. 1993. Building communities from the inside out: a path toward finding and mobilizing a community's assets. Chicago: ACTA.

LARSON, R., RICHARDS, M.H., SIMS, B. \& DWORKIN, J. 2001. How urban African American young adolescents spend their time: time budgets for locations, activities, and companionship. American journal of community psychology, 29:565-597.

LOUW, D.A., VAN EDE, D.M. \& LOUW, A.E. 1998. Menslike ontwikkeling. Pretoria: Kagiso.

MACKEY, J. \& GREIF, G. 1994. Using rituals to help parents in the school setting: lessons from family therapy. Social work in education, 16(3):171178.

McMILLAN, J.H. \& SCHUMACHER, S. 2001. Research in education: a conceptual introduction. Virginia: Longman.

MILLER, W.L. \& CRABTREE, B.F. 2000. Clinical research. (In Denzin, N.K. \& Lincoln, Y.W., ed. Handbook of qualitative research. California: Sage. p. 607-631.)

NICHOLS, M. \& SCHWARTZ, R. 2000. Family therapy: concepts and methods. Needham Heights: Allyn \& Bacon.

OSWALD, R.F. 2002. Inclusion and belonging in the family rituals of gay and lesbian people. Journal of family psychology, 16:428-436.

PASUPATHI, M. 2001. The social construction of the personal past and its implications for adult development. Psychological bulletin, 127:651-672.

PATTON, M.Q. 2002. Two decades of developments in qualitative inquiry: a personal, experiential perspective. Qualitative social work, 1(3):261-283.

POPENOE, D., CUNNINGHAM, P. \& BOULT, B. 1998. Sociology. 1st South African ed. Johannesburg: Pearson Education.

ROBERTS, J. 1988. Setting the frame: definition, functions, and typology of rituals. (In Imber-Black, E., Roberts, J. \& Whiting, R., ed. Rituals in families and family therapy. New York: Norton. p. 72-93.)

SCHUCK, L.A. \& BUCY, J.E. 1997. Family rituals: implications for early intervention. Topics in early childhood special education, 17(4):447-494.

SCHWANDT, T.A. 2000. Three epistemological stances for qualitative inquiry: interpretivism, hermeneutics, and social constructionism. (In Denzin, N.K. \& Lincoln, Y.S., ed. Handbook of qualitative research. California: Sage. p. 189-214.) 
SELIGMAN, M.E.P. 2002. Positive psychology, positive prevention, and positive therapy. (In Snyder, C.R. \& Lopez, S.J., ed. Handbook of positive psychology. Oxford: Oxford University Press. p. 3-13.)

ST. CLAIR, M. 2004. Object relations and self psychology: an introduction. Belmont: Thompson/Brooks/Cole.

STAKE, R.E. 2000. Case studies. (In Denzin, N.K. \& Lincoln, Y.S., ed. Handbook of qualitative research. California: Sage. p. 435-454.)

TERRE BLANCHE, M. \& DURRHEIM, K. 2002. Research in practice: applied methods for the social sciences. Cape Town: University of Cape Town Press.

WENAR, C. \& KERIG, P. 2005. Developmental psychopathology: from infancy through adolescence. Singapore: McGraw-Hill Higher Education.

\section{Kernbegrippe:}

bategebaseerde benadering betekenisgewing

gesinsritueel

\section{Key concepts:}

asset-based approach

giving of meaning

family ritual 